VADIM ERMAKOV ${ }^{\prime}$, LARISA JOVANOVIĆ ${ }^{*}$, ZORAN ČAJKA

1V.I. Vernadsky Institute of Geochemistry and Analytical Chemistry, Moscow, Russia, 2University ALFA, Belgrade, Serbia, ${ }^{3}$ University Singidunum, FEFA, Belgrade, Serbia
Review paper

UDC:504.75.05:711.4

doi:10.5937/ZasMat1503251E

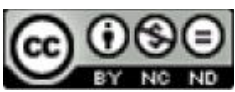

Zastita Materijala 56 (3)

$251-260$ (2015)

\title{
A city as an urban taxon of the biosphere and a problem of waste
}

\begin{abstract}
A number of environmental characteristics of the city as a special biospheric urbanized taxon, including important issues of inventory collection, recycling and the development of closed technological systems are analyzed in this article. Improving solid waste management is one of the most effective ways to strengthen overall municipal management and is usually an important condition for other, more complicated, municipal services. Solid waste is unavoidably linked to urbanization and overall economic development. Today, more than 50 percent of the world's population lives in cities, and the rate of urbanization is on the rise. By 2050, as many people will live in cities as the population of the whole world in 2000. This will certainly add various challenges to waste disposal. Citizens, corporations, and cities will likely need to assume more responsibility for waste generation and disposal, especially in the area of product design and waste separation.
\end{abstract}

Keywords: city, garbage, eco system, urbanized taxon, pollution, wastes.

\section{INTRODUCTION}

The formation of a town as enclosed and alienated territory to developed crafts has been known since antiquity. Under profitable conditions i.e. the availability of adequate sources of food and energy, the area of the city, absorbing the areas of land suitable for development, has increased. Currently, the city can be seen as urbanized taxon biosphere that consumes enormous amounts of water, food and energy (Fig. 1) and tends to a relative autonomy. The city as an ecosystem is significantly different from natural ecosystems [6-12].

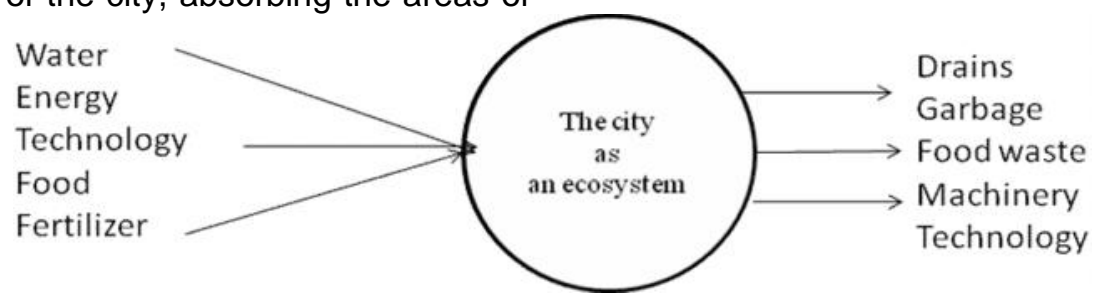

Figure 1 - Incoming and Outgoing Flows of Matter, Energy and Information to the City as an Urban Ecosystem

However, the dependence of town on suppliers of energy and food is great. The desire of the city for independent functioning is relative, but it exists in relation to the presence of food processing. A city can have chicken farms, greenhouses, but this is insufficient to ensure urban food. Great cities often suffer from a lack of quality of air, water, greenery, and a modern fleet of personal use, and these issues aggravate the ecological situation of the city. In addition, the manifestation of the epidemic in this metropolitan area is associated with greater risk for its inhabitants [1-5].

\footnotetext{
*Corresponding author: Larisa Jovanović

E-mail: larisa.jovanovic@alfa.edu.rs

Paper received: 14. 03. 2015.

Paper accepted: 05. 05. 2015.

Paper is available on the website:

www.idk.org.rs/casopis
}

\section{PROBLEM OF GARBAGE AND WASTE PRODUCTS POLLUTION}

The functioning of the biosphere is always accompanied by processes of formation of detritus - excrement, dying and decay products of organisms that are best used in biogeochemical cycles. However, during the period of man-made transformation of the biosphere, people establish a habitat with a lot of substances that negatively affect not only humans, but also other organisms, accompanied by a decline of biodiversity and the blocking of some biosphere functions (Fig. 2). The basic causes of pollution are use of fossil fuel and atomic energy; modern technologies of preparing food; wide application of detergents, fertilizers, and plastics; hazard biological and other waste; products of industry and metallurgy, building materials, and drugs. 
This list is quite long, but in concentrated form, is primarily production and consumption waste. Common questions about the technological evolution of the biosphere are closely related to the global problem of "garbage", which is slowly being solved by the international community.

\begin{tabular}{|c|c|}
\hline SPHE & $\mathrm{T}$ \\
\hline $\begin{array}{c}\downarrow \\
\text { Whole organisms, } \\
\text { besides man } \\
\downarrow \\
\text { Products of die off } \\
\text { and decomposition, } \\
\text { excrements } \\
\downarrow\end{array}$ & $\begin{array}{l}\quad \text { H u m a n } \\
\text { Field filtration, precipitation, } \\
\text { crematory, industrial waste: the } \\
\text { products of burning oil, coal, gas, } \\
\text { detergents, plastics, mineral oils, } \\
\text { fertilizers, ore, scrap metal, toxic } \\
\text { substances, radionuclides. }\end{array}$ \\
\hline $\begin{array}{l}\text { Maxima utilization of } \\
\text { matter in the cycles }\end{array}$ & \\
\hline$\downarrow$ & $\begin{array}{l}\text { Isolation of substances from } \\
\text { the cycles with predominance } \\
\text { metals, radionuclides, } \\
\text { organic chemicals }\end{array}$ \\
\hline
\end{tabular}

\section{Figure 2 - Some Signs of Urban and Natural Ecosystems}

Waste production can be divided into radioactive, medical, biological, construction, waste transport sector, and industrial. With regard to the identification, assessment and remediation of ore and mining companies, there are numerous technology recycling dumps, heaps, tailings content, quarries, etc. At this stage, such local areas are in need of localization, accounting, periodic monitoring, and transformation. It is necessary to identify the main types of waste and guidelines for their disposal.

By the early 1990's, in Russia, there had been disposed about $70 \%$ of the total amount of toxic industrial wastes of the Soviet Union, including all types of largest-volume wastes (used forming mixtures, slate processing wastes, oil slimes, galvanic slimes, oil wastes, etc.). Besides that, over 1.6 billion tons of toxic industrial wastes had been accumulated in Russia. Every year, this amount increased by 50 million tons, and only $20 \%$ of it was recycled. Today, about 80 thousand types of various chemical wastes are produced in the world at a total rate of about 300 million tons per year $[13,14]$.

New Yorkers throw away a total of 24,000 tons of different materials per day. This vast mixture, consisting mainly of various junk, contains valuable metals, glass containers, suitable for further use, as well as waste paper, plastic, and food waste, which are essential for fertilization. But along with them, this mixture contains an even greater number of hazardous waste: batteries, mercury, phosphorus, carbonates of fluorescent bulbs and toxic chemicals from household solvents, and paints. A growing amount of waste and lack of recycling is typical of many cities.

Military actions make a considerable contribution to the process of environmental pollution. As a result of the Second World War, thousands of tons of metals were piled on battlefields. The comparatively small-scale military action of NATO in Yugoslavia in 1999 resulted in the growth of consumption of such toxic elements as lead $(\mathrm{Pb})$, cadmium (Cd), arsenic (As), mercury $(\mathrm{Hg})$ and uranium $(\mathrm{U})$ caused by air, water and soil pollution in Serbia, and by improper quality of imported foodstuffs or products supplied as humanitarian aid $[3,12,15]$.

According to assessments of the RF State Commission for Ecology (Goskomekologia), the integral impact of military forces on the environment in peaceful time is comparable to the effects of one medium-size industry (about $4 \%$ of the total effluent discharge and $1.2 \%$ of atmospheric emissions). In the opinion of the Directorate for Ecology and Special Protection Facilities of the RF Ministry of Defense, actual emission and discharges of military sites (garrisons) are comparable to those of small and medium enterprises [14].

Particular concerns among civilization-related changes to the environment are caused by its pollution by industrial and household wastes. As has been previously mentioned, the greatest risk is posed by different types of toxic substances.

In our opinion, a pollutant is a substance or a mixture of substances of technogenic or natural origin, which disturbs the cycles of migration of chemical elements and energy conversion and interferes with the functioning of ecosystems in general. Pollution is a process of inflow and integration in the ecosystems of technogenic or natural substances in amounts toxic for the ecosystems or promoting the formation of new dangerous compounds. They can be classified according to the chemical structure, source, type of production, mechanism of affecting organisms, migration and transformation features.

In order to prevent environmental (soil, ground, water) contamination from taking an irreversible and catastrophic form, one needs to revise the strategy of nature utilization, and eliminate ways and sources of further pollution of the geological environment, on the one hand, and to develop and implement methods and technologies to suppress toxicity and clean up different constituents of the geological environment from such pollutants, on the other $[16,17]$. 
Cleanup technologies are an intermediate step on the way from technospheric to noospheric transformation. These will be used until mankind develops environmentally clean closed technologies.

One of the key tasks in this area is to develop recycling technologies. Disposal of toxic wastes is a forced practice of limited use. This potentially hazardous tradition should be replaced with waste reprocessing technologies, concentration, inactivation with secondary utilization in closed cycles. Wastes of different productions (effluent, tailings, slimes, non-utilizable waste, sewage tanks, etc.) are products of imperfect technologies that need to be rejected as soon as possible and replaced with improved ones, including closed cycles [15-20].

According to V. A. Korolev [13], three major methodical approaches can be used for the prevention of pollution. The first is to clean soils by direct removal of hazardous components through their withdrawal from an object, by cleaning or by other methods. The pollutants thus removed from the soil body need to be recycled outside the soil body. The second approach rests upon in situ detoxication, instead of removal, of a pollutant, directly in the soil body, for example, by its neutralization, decomposition (destruction), binding, etc. The third approach is based on the construction around the anomaly of a shield to prevent further propagation of contamination (the Chernobyl's "sarcophagus") [18].

One also makes use of natural self-purification mechanisms. This approach rests upon the processes of abiotic and biotic transformation of chemical pollutants.

The following in situ processes can be used as applied to pollutants incorporated in solid-state rock (soil) or absorbed by it: 1) chemical neutralization + leaching (or dilution) + removing products together with solution; 2) treatment with adsorbents (physical and chemical processes) + biodegradation + removing products together with solution; 3 ) in situ chemical or physical (thermal) hardening + biodegradation + constructing a shield; 4) thermal destruction + leaching + removing products together with solution, containing the polluted area and removing earth $[10,16,17]$.

The following chelation processes can be used, if a pollutant is in the liquid phase of the rock body: 1) evacuation (probably, with thinning) + water purification on the surface; 2) electro treatment + evacuation + water purification on the surface; 3 ) chemical or physical and chemical neutralization (precipitation) + biodegradation + shield (or removing products with solution); 4) thermal destruction + biodegradation + shield (or removing products with solution).
If a pollutant is in the gas phase or if it is an absorbed gas, then the following in situ processes can be used: 1) thermal treatment + vacuum extraction + shield; 2) biodegradation + evacuation + purging; 3 ) chemical or physical and chemical neutralization + purging (or evacuation) [14]. In addition to the above purification processes, one needs to mention electrokinetics, which is widely used for purifying soils, phytostabilisation, and phytoextraction. As applied to soils, the inflow of heavy metals is corrected by means of appropriate fertilizers and additives $[4,10,15]$.

Another independent problem arises and that is what we should do with the pollutant. That is, the matter concerns recycling of final purification products or disposal of toxic substances withdrawn from the environment. They should not be simply stored in landfills because this leads to secondary pollution of the environment. They should undergo industrial reprocessing, recycling or final decomposition into non-toxic compounds.

Apparently, two principles need to be kept in mind in developing strategies for struggling against pollutants: 1) not to establish production that disturbs relatively natural biogeochemical cycles of chemical elements, 2) give preference to technologies with closed cycle and minimum interference with natural processes. In both cases, one should stay within the known migration cycles of substances, which maintain the comfortable life of organisms and normal functioning of ecosystems.

The whole established system of commercial production needs to be restructured in order to make it non-waste or low-waste based on comprehensive recycling and to ensure environmentally safe and adequate level of waste disposal [19].

The volume of solid waste (MSW) in Moscow is made up of two streams: from housing and from public and commercial organizations and agencies (table 1). In quantitative terms, flows up from the housing stock - 1.9 million tons /year $(60 \%$ of collected MSW), from public and commercial organizations and institutions - 1.2 million tons / year $(40 \%$ of collected MSW).

The sanitation of the city of MSW is currently based on the following proposals: improving the system for collecting and transporting solid waste, the transition to two-stage removal of solid waste by the construction of garbage processing plant, the introduction of industrial methods of processing solid waste based on the construction new garbage and incinerators factories and reconstruction of existing, the commissioning of new and restoration of existing solid waste landfills in accordance with modern environmental requirements [11]. 
Among the technologies used to correct microelementoses in humans, there should be mentioned the development and application of numerous food additives. Unfortunately, in most cases, they are administered irrespective of daily consumption of macro- and microelements and without assessing their environmental status, which may lead to undesirable effects. In animal husbandry and veterinary, correction of mineral metabolism is more efficient because the composition of fodder is known in most cases. Metal compounds, radionuclides, and toxic substances are detoxicated by means of sodium thiosulphate, derivatives of pyrrolidone, humic acids, zeolites, pectin and various antidotes $[5,15,16,22]$. However, in order to make a timely decision on prescribing prophylactic or treatment procedures, special diagnosis techniques are needed, for example, the diagnosis of microelementoses based on the chemical elemental composition of hair [9].

\section{AREAS OF ENVIRONMENTAL STRESS}

Areas of environmental stress or areas with special conditions of nature utilization and economic activity were designated formally because of actual technogenic transformation in the most part of Russia.

Table 1 - Disposal of Waste Products of Moscow (according to the Department of Natural Resources and Environment) [11]

\begin{tabular}{|c|c|c|c|c|}
\hline \multirow{2}{*}{ No } & \multirow{2}{*}{ Name of the waste type, and company-processor } & \multicolumn{3}{|c|}{ Adapted / adopted, t / year } \\
\hline & & 1999 & 2000 & 2011 \\
\hline \multicolumn{2}{|r|}{$\begin{array}{c}\text { Total industrial waste recycled, including: - processed } \\
\text { - handed over for processing outside of Moscow } \\
\text { - buried in the landfill, "Salarevo" }\end{array}$} & $\begin{array}{c}1926707 \\
301619(15 \%) \\
385088(20 \%) \\
1240000(65 \%)\end{array}$ & $\begin{array}{c}1601888 \\
337222(21 \%) \\
408666(25 \%) \\
856000(54 \%)\end{array}$ & $\begin{array}{c}1896719 \\
570922(30 \%) \\
80738(25 \%) \\
845059(45 \%)\end{array}$ \\
\hline 1 & Electroplating waste & 306.75 & 357.64 & 514.41 \\
\hline 2 & Spent fluids and electrolytes & 375.35 & 375.19 & 836.10 \\
\hline 3 & Mercury-containing waste & 1297.13 & 1700.00 & 2005.00 \\
\hline 4 & Precipitate treatment facilities & 6869.76 & 3182.20 & 8295.87 \\
\hline 5 & Petroleum waste & 4328.50 & 5977.66 & 8751.06 \\
\hline 6 & Liquid organic wastes, including coolant & 1899.05 & 1798.80 & 1615.00 \\
\hline 7 & Chlorinated wastes including perchlorethylene & 14.40 & 113.46 & 109.40 \\
\hline 8 & Sludge and paint waste & 616.10 & 649.26 & 827.65 \\
\hline 9 & Oily rags, sawdust, paper, and filters & 841.95 & 1096.00 & 1230.90 \\
\hline 10 & Spent lead-acid battery & 4000.00 & 6000.00 & 6465.54 \\
\hline 11 & Waste polyethylene & 973.00 & 756.05 & 1384.32 \\
\hline 12 & Medications, medical waste, chemicals, cosmetics & 120.11 & 179.30 & 212.92 \\
\hline 13 & Biological waste & 3282.00 & 1911.00 & 340.80 \\
\hline 14 & Proven car parts and rubber products & 6889.70 & 9063.00 & 9632.10 \\
\hline 15 & Window & 21600.00 & 32850.00 & 35728.00 \\
\hline 16 & Photo waste & 325.10 & 756.72 & 985.60 \\
\hline 17 & Construction waste & 226728.00 & 251600.00 & 465530.00 \\
\hline 18 & Wood waste & 5640.00 & 1881.00 & 1036.00 \\
\hline 19 & Black metal & 15543.00 & 20046.00 & 25129.00 \\
\hline 20 & Colorful scrap & & 1227.80 & 266.30 \\
\hline 21 & Metal-containing sludge and dust & & & 25129.00 \\
\hline
\end{tabular}

The disturbance of natural balance in most of Russia's territory, and, consequently, deterioration of health and living conditions of the population necessitated the establishment of a legal status of areas of environmental stress [21]. They differ in conditions and mechanism of origin, procedures to declare their legal status, arrangement and practices for mitigating adverse effects of unfavorable conditions in the area. The ultimate aim of these practices is to ensure constitutional rights of every person to live in the ecologically safe environment.

In compliance with the RF Law on Environmental Protection, parts of the territory of Russia, where economic and other activities cause stable negative changes in the environment that threaten human health, ecological systems and gene pool of plants and animals, are declared areas of environmental emergency (Article 58). 
Territories with dramatic irreversible environmental changes that entailed considerable health deterioration, disturbance of natural equilibrium, damage to natural ecological systems, degradation of flora and fauna are declared areas of environmental disaster (Article 59).

According to the Water Code of the RF (Article 116), water bodies, their parts and drainage areas can be declared areas of environmental emergency and environmental disaster.

In compliance with the Forest Code (Article 46), assigning the above status to forest areas belongs to the jurisdiction of the RF.

Areas of environmental emergency are declared in accordance with governmental resolutions or decrees of the RF President based on statements of the state ecological inspection based on materials and data of area examination against environmental assessment criteria $[1,2]$.

The Kuznetsk Basin in Kemerovo region and the cities of Nizhniy Tagil and Bratsk were declared areas of environmental emergency having passed the above state environmental assessment procedure, and a number of territories were included in the list of recovery and social and environmental rehabilitation [19].

Unfortunately, a great number of regions in Russia (northern territories, Eastern Siberia) proved to be insufficiently explored in terms of environmental safety, in spite of some radioecological and geochemical assessments made in some marine areas and continental taxons of the biosphere. The environmental and health assessment is carried out according to the Criteria for Environmental Assessment of Territories to Reveal Areas of Environmental Emergency and Disaster [2].

Within the framework of the program "Environmental Safety of Russia", in 1993-1995, the criteria were tested in Astrakhan, Irkutsk, Moscow, Perm' and Chelyabinsk regions, in the cities of Angarsk, Dzerzhinsk, Mednogorsk, Novocherkassk and Kirovo-Chepetsk, and in the republics of Sakha-Yakutia and Kalmykia. Relatively satisfactory, conflict, stressed, crisis and disaster territories with individual environmental problems (general water pollution, disturbed conditions, salinity, etc.) were revealed [21]. By ranking the territories, the necessity of establishing areas of environmental stress (areas of environmental stress) through legislation has emerged, where adverse changes in the environment started to occur as a result of economic activity, and where prevention and prophylactic actions needed to be implemented. Taking this into account, the Law on Environmental Protection was correspondingly revised and supplemented.
The environmental threat is characterized by an integral value of risk: $R=p \times y$. Risk is determined as a product of the probability ' $p$ ' of adverse effects on the public, territory, population, objects of nature, etc. caused by a source of environmental threat (polluted object of nature) and damage ' $y$ ' caused by these effects [21].

If necessary, one can determine the status of zones as follows: zones to be emptied or evacuated; zones where residents can stay, but have a right to leave, and zones where residents have social and economic privileges.

\section{PLANNING OF INTEGRATED WASTE MANAGEMENT}

Countries in transition, like most developing countries, have big problems with the disposal of municipal waste. Disposal at unequipped landfills (dumps) creates a risk to human health and degrade the environment. We should indicate some basic risks of existing landfills in Serbia:

- Contamination of soil and groundwater by filtrates

- Surface water pollution

- Uncontrolled combustion

- Migration of landfill gas into the soil and water

- Landslides of unstable waste

- The risk of epidemics due to the appearance of pests, insects, and birds

- Endangering the health of workers at landfills and the population

- Damage to flora

- Explosions and fires

- Dust and odors

Improper waste management can have adverse effects on human health, the environment, and natural resources. Adequate treatment of municipal solid waste is important to human health but because of the additional political and economic reasons, as well as a significant impact on the quality of the environment, it deserves greater attention of local authorities.

Planning of integrated waste management should include the prevention of waste (minimizing the production of waste materials) and the recycling of waste, (including composting and making fertilizers) so that they have priority over other options [23-25] It is necessary to introduce new methods of treatment of batteries and accumulators and the recycling of plastic packaging.

The European Union and various institutions provide financial assistance for waste management projects in the candidate countries, such as the IPSA instruments of the European Union. In developing strategies for the waste management, candidate countries have to consider the sources of funding. 
Serbia and other candidate countries have to carry out the harmonization of legislation with the EU regulations in the field of waste management. The transition period will be followed by negotiations between the candidate countries and the European Union. Implementation tasks will be time-consuming and they will comprise the following issues:

- Development and improvement of strategy and implementation plans

- Development of appropriate institutional arrangements and ways of regulating and sanctioning a breach of regulations

- Planning, design and construction of new infrastructure and facilities

- Securing permits for new infrastructure and facilities

It is necessary to perform the analysis of significant problems and flaws in the existing arrangements and waste management practices, and their impacts and effects. Identification and systematic analysis are particularly inadequate in the following areas:

- Legislation

- Activities of institutions

- Availability of data on quantities and methods of waste disposal

- Working practices in energy waste.

The strategic waste management policy must consider each of the identified problems and weaknesses, and all the objectives should be translated into measurable and verifiable indicators.

Waste management is important for local authorities because it is a service that is rendered to a large number of users. Inadequate provision of these complex services can lead to large and serious problems for local authorities that can cause dissatisfaction of citizens and increase distrust. Utilities claim a considerable part of the local budget and include a significant number of public sector employees. The number of those who find jobs related to waste is much higher if we take into account the so-called " informal sector " for the collection and processing of waste.

Local authorities are faced simultaneously with a large number of complex issues around the boardroom management. Municipal systems, in the majority of municipalities in the country, consist of public utilities. Disadvantages of these systems include the absence of a good strategic framework for waste management, lack of resources and legal instruments to improve the efficiency, effectiveness and sustainability of the operations of these systems.

The most common practical problems are related to inadequate or poorly maintained and outdated equipment with insufficient spare parts.
The equipment is inadequate for modern requirements, which is even more pronounced because of the increase in population and the amount of waste that is produced.

Financial problems are related to the imbalance between income and expenses, mainly due to unforeseen cost increases and failure to achieve planned annual revenue. On the financial side, there are offers of rather expensive and inefficient waste processing equipment. Other unfavorable issues are increased costs and delays caused by regionalization, increased distance to places of disposal and higher value of land located in surrounding cities.

A large number of unregistered intermediaries, who perform activities of traffic management, constitute the so-called black market for secondary raw materials. It is known that they operate outside the legal regulatory framework. This "informal system" for the collection and processing of waste and recycling businesses is usually considered as a problem rather than as a serious business partner in the field of waste management.

The concept of solving the problem of municipal solid waste management is based on the principles of sustainable development and is called the "Integrated Sustainable Solid Waste Management". This concept emphasizes the role that the participants have in the accumulation of waste waste collectors and generators (companies, households, educational and medical institutions, farms, etc.), and in the movement of waste [26]. This concept comprises practical and technical elements of waste management systems that include prevention, minimization, separation, recycling, composting and reuse components.

By linking institutional, social, technical and financial aspects, the concept of integrated waste management realizes the distribution of roles that different participants have in waste management and in all operations with the waste from collection and classification - to processing, composting and disposal at sanitary landfills. Also, this concept defines a number of concepts and instruments for solving the waste problem in municipalities first and then at the regional level, to serve as a framework for understanding the problem, and then to search for solutions. This kind of approach to the problem is important because the long-standing gaps in the treatment of waste in our country are related to inadequate analysis of the problem, which led to extraordinary situations and the increase of waste problems.

In the aim of the ultimate benefits of citizens, and in accordance with the paradigm of sustainable development, it is necessary to ensure quality provision of utility services through adequate waste management. 
When natural waste happens to appear in the environment (for example, as a result of volcanic eruptions, forest fires, carbon dioxide emissions from organisms, decomposition of vegetation or organisms, etc.), then there is disruption of the balance of the ecosystem. However, the ecosystem is able to quickly restore the quality of the habitat and the ecosystem balance is reestablished. In other words, all the waste created in nature serves as a food or energy to other types of systems as input to complementary natural processes. As a result, waste in the nature is continuously consumed and absorbed by or is converted in the natural products.

However, enormous amounts of waste generated by men are major problems for ecosystems. The amount and composition of the waste depend on factors such as population, lifestyle, and technology.

There is no doubt that the waste is the major problem for humanity. Total production of waste in the world is growing on a daily basis. Table 2 shows trends in daily per capita municipal solid waste generation in the United States in the period between $1960-2010$.

Between 1960 and 1988, the daily production of municipal solid waste in the United States increased from $1.3 \mathrm{~kg}$ to $2 \mathrm{~kg}$ per person, i.e. 48.2 $\%$. From 1988 to 2010, an increase in the amount of waste per capita was projected from $2 \mathrm{~kg}$ to 2.3 $\mathrm{kg}$, or $15 \%$ increase [27].

It is hard to imagine what would happen if nine billion people would produce waste at the level of an average American citizen. With greater population and a higher standard of living, the production of waste in the world will continue to grow. Although technologies can be considered as the cause for the generation of waste, they can, nonetheless, be regarded as an important part of the solution. The application and use of modern technology through the application of modern marketing practices can resolve most of the accumulated environmental problems. The new paradigm of sustainable marketing management allows this connection while at the same time suggests that changes in population and wealth / average consumption also are important factors that can be resolved by adopting appropriate legislation.

Ecosystems are used as a source of resources and a place for disposal of the total waste.

Marketing functions facilitate consumption and increase many interrelated economic activity, trade and consumer activities. As population grows, the level of wealth increases, and the number of actions required to meet the growing needs of the population is also growing. It is also affected by the increase in the volume of waste, environmental pollution, and the destruction of habitat. Sustai- nable marketing management is necessary for solving the problems.

Table 2 - Trends in Daily per Capita Municipal Solid Waste Generation in the United States in the Period between $1960-2010$.

\begin{tabular}{|c|c|c|c|}
\hline Year & $\begin{array}{c}\text { Municipal Solid } \\
\text { Waste Gene- } \\
\text { ration (millions } \\
\text { of tons) }\end{array}$ & $\begin{array}{c}\text { Population } \\
\text { (millions) }\end{array}$ & $\begin{array}{c}\text { Per Capita } \\
\text { per Day } \\
\text { (kgs) }\end{array}$ \\
\hline 1960 & 87.8 & 180.7 & 1.3 \\
\hline 1970 & 121.9 & 205.1 & 1.5 \\
\hline 1980 & 149.6 & 227.7 & 1.7 \\
\hline 1988 & 180.0 & 245.0 & 2.0 \\
\hline 2000 & 216.0 & 274.6 & 2.2 \\
\hline 2010 & 250.6 & 297.7 & 2.4 \\
\hline
\end{tabular}

Source: US Bureau of the Census (1997), Current Population reports (P25-1045, P25-1103, P25-1126)

Pollution can be defined as any substance that adversely affects the physical, chemical, or biological quality of the earth $s$ environment or that accumulates in the cells or tissues of living organisms in amounts that threaten the health or survival of these organisms [28].

The environmental imperative is absolutely essential, as the world economy continues to grow at a fast pace and thus threatens the environment and the survival of ecosystems. If we do not take appropriate measures to ensure that production is under control without reducing eco-costs, consumption at a high level will not be sustainable. There is an evident interdependence of the global environment and the global economy. A man is forced to deal with the increasing number of environmental problems. The economy and the environment are becoming increasingly dependent - locally, nationally and globally. Marketing cannot be isolated from these environmental problems. Marketing must address the problems of resources used to meet the needs and desires of consumers, as well as the problems of the impact of this spending on human life, ecosystems and the environment as a whole. There is no doubt that sustainable development requires sustainable marketing management [27].

\section{GLOBAL WASTE GENERATION}

The amount of solid waste in the world is growing faster than the rate of urbanization. The MSW has become one of the most important byproducts of an urban lifestyle. Many cities in the world are striving to manage their waste in an effective manner. Waste volumes are increasing at a fast pace everywhere in the world - even faster than our modern urbanization. There is a significant and obvious correlation between urban solid waste generation rates and GHG emissions. Analyzing MSW in an integrated manner, and focusing on 
urban form and lifestyle choice may produce broader benefits.

Current MSW generation levels in the world are about 1.3 billion tonnes per year. These levels are expected to increase to over 2.2 billion tonnes per year by 2025. This increase represents a significant rise in per capita waste generation rates, from 1.2 to $1.42 \mathrm{~kg}$ per person per day in the next fifteen years. Global averages are only broad estimates as rates vary considerably by region, country, and city [28].

MSW generation rates are influenced by many factors, such as economic development, the degree of industrialization, public habits, and local climate. It is known that the amount of solid waste production depends on the economic development and rate of urbanization. Income level and urbanization are also highly connected and as disposable incomes and living standards are on the rise, consumption of goods and services is also on the rise, as does the overall amount of waste generated. Urban residents are likely produce more than twice as much waste as their counterparts in rural areas.

Waste generation varies as a function of wealth in the country or region. Regional and country variations can be significant. Generation rates within the same city can also be significant.

Waste generation in sub-Saharan Africa amounts to about 62 million tonnes per year. Per capita waste generation is rather low in this region, but with a wide range from 0.09 to $3.0 \mathrm{~kg}$ per person per day, and with an average of $0.65 \mathrm{~kg} /$ capita/day. Various islands are countries with the highest per capita rates, likely due to waste generated by the developed tourism industry.

The waste generation in East Asia and the Pacific Region is approximately 270 million tonnes per year. This large quantity is mainly influenced by massive waste generation in China, which makes up $70 \%$ of the regional total. Per capita waste generation is in the range from 0.44 to $4.3 \mathrm{~kg}$ per person per day, with an average of 0.95 $\mathrm{kg} /$ capita/day.

In Eastern and Central Asia, the waste generated per year is 93 million tonnes. Several countries in this region have no available data on waste generation. The waste generation per capita ranges from 0.29 to $2.1 \mathrm{~kg}$ per person per day, and with an average of $1.1 \mathrm{~kg} /$ capita/day.

Latin America and the Caribbean has the most comprehensive and reliable data. The total amount of waste generated on a yearly basis in this vast region is 160 million tonnes, with per capita ranging from 0.1 to $14 \mathrm{~kg} /$ capita/ day, and an average of $1.1 \mathrm{~kg} /$ capita/day. The largest per capita solid waste generation rates are found in the islands of the Caribbean.
As for the Middle East and North Africa, annual solid waste generation ia about 63 million tonnes. Per capita waste generation is in the range of 0.16 to $5.7 \mathrm{~kg}$ per person per day, and with an average amount of $1.1 \mathrm{~kg} /$ capita/day. The OECD countries produce about 572 million tonnes of solid waste per year. As for per capita values, they range from 1.1 to $3.7 \mathrm{~kg}$ per person daily and with an average amount of $2.2 \mathrm{~kg} /$ capita/day [28]. In South Asia, about 70 million tonnes of waste is produced on a yearly basis, with per capita values ranging from 0.12 to $5.1 \mathrm{~kg}$ per person per day and an average of $0.45 \mathrm{~kg} /$ capita/day. (see Table 3 ). Table 3 shows current waste generation per capita by region. The table clearly shows the lower boundary and upper boundary for each region, as well as average $\mathrm{kg}$ per capita per day of waste generated within each region in the world.

Table 3 - Current Waste Generation per Capita by region ( $\mathrm{kg} /$ capita/day)

\begin{tabular}{|l|c|c|c|}
\hline \multicolumn{1}{|c|}{ Region } & $\begin{array}{c}\text { Lower } \\
\text { boundary }\end{array}$ & $\begin{array}{c}\text { Upper } \\
\text { boundary }\end{array}$ & Average \\
\hline Africa & 0.09 & 3.0 & 0.65 \\
\hline $\begin{array}{l}\text { East Asia \& the } \\
\text { Pacific }\end{array}$ & 0.44 & 4.3 & 0.95 \\
\hline $\begin{array}{l}\text { Eastern \& } \\
\text { Central Asia }\end{array}$ & 0.29 & 2.1 & 1.1 \\
\hline $\begin{array}{l}\text { Latin America } \\
\text { \& Carribean }\end{array}$ & 0.11 & 14 & 1.1 \\
\hline $\begin{array}{l}\text { Middle East \& } \\
\text { North Africa }\end{array}$ & 0.16 & 5.7 & 1.1 \\
\hline OECD & 1.10 & 3.7 & 2.2 \\
\hline South Asia & 0.12 & 5.1 & 0.45 \\
\hline
\end{tabular}

Source: Hoornweg, D. and Perinaz Bhada-Tata What a waste: A Global Review of Solid Waste Management, The World Bank March, 2012 No. 15 Washington, DC Urban development series knowledge papers, p. 9

Table 4 - Waste Generation (projection by 2025) biological and other waste

\begin{tabular}{|l|c|c|c|c|}
\hline \multicolumn{4}{|c|}{ Projections for 2025} \\
\hline \multicolumn{2}{|c|}{ Projected Population } & \multicolumn{2}{c|}{$\begin{array}{c}\text { Projected Urban } \\
\text { Waste }\end{array}$} \\
\hline Region & $\begin{array}{c}\text { Total } \\
\text { population } \\
\text { in millions }\end{array}$ & $\begin{array}{c}\text { Urban } \\
\text { population } \\
\text { in millions }\end{array}$ & $\begin{array}{c}\text { Per capita } \\
\text { (kg/capita/day) }\end{array}$ & $\begin{array}{c}\text { Total } \\
\text { (tons/day) }\end{array}$ \\
\hline AFR & 1,152 & 518 & 0.85 & 441,840 \\
\hline EAP & 2,124 & 1,229 & 1,5 & $1,865,39$ \\
\hline ECA & 339 & 239 & 1,5 & 354,810 \\
\hline LCR & 681 & 466 & 1,6 & 728,392 \\
\hline MENA & 379 & 257 & 1,43 & 369,320 \\
\hline OECD & 1,031 & 842 & 2.1 & $1,742,47$ \\
\hline SAR & 1,938 & 734 & 0,77 & 567,545 \\
\hline Total & 7,644 & 4,285 & 1,4 & $6,069,73$ \\
\hline
\end{tabular}

Source: Hoornweg, D. and Perinaz Bhada-Tata What a waste: A Global Review of Solid Waste Management, The World Bank March, 2012 No. 15 Washington, DC Urban development series knowledge papers, p. 10 
Table 4 shows estimates of waste generation for the year 2025 as expected according to current trends in population growth in each region. Projections for urban municipal solid waste generation in 2025 were made by factoring expected growth in population and GDP and estimated per capita waste generation. As can be seen from the table, the projected urban waste will amount to about $2.1 \mathrm{~kg} /$ capita/day in the OECD countries, or 1,742, 417 tons per day.

\section{CONCLUSION}

A new form of interaction between society and nature is being established today; an involved legal, environmental, economic, scientific and engineering problem arises: to ensure environmental safety. A new type of activity is emerging - the protection of population and territories from natural and technogenic emergencies.

The problem under consideration is closely related to the matters of evolution of Earth's biosphere. The development of the technosphere and an increased amount of technogenesis products are finite because they stimulate the development in the biosphere of a noosphere - the era of the supremacy of intellect.

There is also a problem of disagreement between society and technology development. The higher level of technology development should correspond to a new stage of development of society and humans themselves in their interaction with nature. Implementation of the noosphere concept does not remove the contradictions between the optimal level of society development and smart technologies. However, under the conditions of the noosphere, such contradictions will become predictable, they will be monitored and removed most promptly and with insignificant energy and information expenses as against the conditions of the biosphere at the stage of early technogenesis.

Focusing attention on consequences of technogenesis, having a negative impact on humans, one needs to mention positive aspects of the scientific and technical revolution. Making use of new energy sources, developing high-reproducibility breeds of animals and plants, getting into the space - these are the results of man's intellectual activity. Due to the scientific and technical revolution, many diseases in farm animals have been conquered and life expectancy of humans has increased.

To solve the problem of wastes we should:

1. Conduct an inventory of waste, their systematization, and environmental assessment.

2. In the environmental assessment of the territories occupied by industrial waste and its toxic components, we should apply "The Criteria for Assessing the Ecological Status of
Territories", developed by the National Russian Programme "Ecological Safety of Russia". To correct these criteria are in line with international approaches and provide the Criteria by methodological guidance on their practical application.

3. Carry out a quantitative evaluation of mineral components of waste production, including rare and dispersed chemical elements (rhenium, osmium, uranium, tantalum, niobium, cadmium, etc.).

4. Develop the technologies of detoxification of toxic waste, recycling and recovery of useful components.

5. In areas of storage of waste containing toxic concentrations of heavy metals, radioactive materials, pesticides and plastics, conduct a comprehensive survey of the population and animals in order to diagnose possible pathologies and microelementoses, their prevention and treatment.

6. Actively promote a differentiated waste storage for recycling.

7. Develop technologies for processing waste and closed ("non-waste") processes.

8. Improve the regulatory framework.

\section{REFERENCES}

[1] M.V. Butorina, P.V. Vorob'ev, A.P. Dmitrieva ( 2002) Engineering Ecology and Ecological Management. M.: Logos,. 528 ps. (in Russian).

[2] Criteria of an assessment of ecological condition of territories for revealing zones of an extremal ecological situation or zones of ecological disaster. Moscow: Min. of ecol. and nat. res. of RF. 1992. 50 ps. (in Russian).

[3] I.Djujic, D.Djordjevic, V.T.Djermanovic, B.M. Djujic (2001) Dietary intakes of trace elements by residemts of Serbia two years after NATO operation "Merciful Angel", Proceedings of 3rd International Symposium on trace elements in human: new perspectives. Athens, Greece, p. 263-280.

[4] G.Dowson, B.Mercer (1996) Rendering of toxiferous waste / translated by V.A. Ovcharenko. M.: Stroyizdat, 288 ps. (in Russian).

[5] V.V. Ermakov (1986) Biological transformation of clororganic and mercury-containing pesticides: Abstract of diss. dr. biol. sciences. ., MVA, 34 ps. (in Russian).

[6] V.V. Ermakov (2005) Technogenesis and biogeochemical evolution of taxons in the biosphere, Ecologica, 9(41), 3-12.

[7] V.V. Ermakov , L.N. Jovanovic (2010) Biodiversity and the biosphere technogenesis, Ecologica, 17(58), 77-85.

[8] V.V. Ermakov, L.N.Jovanovic (2010) Selenium deficiency as a consequence of human activity and its correction, Journal of Geochemical Explor., 107,193-199. 
[9] V.V.Ermakov, S.F. Tyutikov (2008) Geochemical ecology of animals. M: Nauka, p.315 (in Russian).

[10] H.K.Hansen, L.M.Ottosen, B.K.Kleim (1999) Electrodialytic remediation of soil polluted with heavy metals. Key parameters for optimization of the process, ICHEME Symposium Series., No. 145 , p. 201-209.

[11] A.G.Ishkov (2003) Implementation of the State Environmental Policy Waste Management in Moscow, Russia, Proceedings of the 4th Scientificmethodical seminar "Waste reduction program: the development and implementation"; on 24-25 February .

[12] L.Jovanovic (2010) Chemistry and Environmental Protection, Tehnika, Beograd, p.315.

[13] V.A.Korolev (2001) Clearing of soils of pollutions. : MAIK "Science/ Interperiodika", p.365 (in Russian).

[14] A.B.Mukherjee (2001) Behavior of heavy metals and their remediation in metalloferous soils, Metals in the Environment (ed. by M.N.V. Prasad). Marcel Dekker, Inc., New Yourk-Basel, p. 433- 471.

[15] L.Jovanovic, D.Bajin (2009) Globalization of Environmental Problems, Ecologica, 54,15-24.

[16] V.A.Korolev, M.A.Ntkrasova (1998) Experimental researches of electrochemical migration of ions of metals in dispersed rocks, Geochemistry, 12, p.1277-1283 (in Russian).

[17] N.P.Laverov, B.I.Omel'yanenko, V.I.Velichkin (1994) Geologic aspects of a problem of a burial of radioactive waste, Geoecology, 6, p. 3-20 (in Russian).

[18] E.I.Mayorova, Yu.A.Butuzov (2003) Ecology and environmental legislation of Moscow. M. UNITY. 2003.

[19] A.T.Nikitin, C.A.Stepanov, Yu.M.Zabrodin (1997) Ecology, nature protection and ecological safety
(Ed. by V.I. Danilov-Danil'yan). M.: Publ. MNEPU,744 ps.(in Russian).

[20] A.K.Riskulov, V.V.Ermakov (1989) Veterinarysanitarian aspects of a pollution of the environment by industrial lets, Control of the contents of pesticides and nitrates in soil, plants and in agricultural production. Frunze, p. 29-31 (in Russian).

[21] S.Jordačijević, L.Jovanović (2010) Concept of integrated solid waste management. International scientific conference "Environment and Biodiversity", Belgrade, Book of Abstracts, pp. 140141.

[22] S.Jordačijević, L.Jovanović, Ž.Radosavljević, M.Anđelković (2010) Koncept integralnog održivog upravljanja otpadom, Ecologica 58, 237-244.

[23] L.Jovanović (2015) Soil pollution in the railway junction Niš (Serbia) and possibility of bioremediation of hydrocarbon-contaminated soil, EGU, Vienna 2015.

[24] L.Jovanović, S.Jordačijević, Ž.Radosavljević, M.Anđelković (2010) Uloga kompostiranja u funkciji povećanja plodnosti zemljišta i očuvanja biodiverziteta, Ecologica 58, 245-250.

[25] D.G.Kaufman, M.F. Cecilia (1993) Biosphere 2000: Protecting Our Global Environment. New York: Harper Collins, p.18.

[26] US Bureau of the Census (1997) Current Population reports (P25-1045, P25-1103, P25-1126)

[27] Z.Čajka, L.Jovanović (2014) Održivi marketing menadžment, Ecologica, Beograd. p.13.

[28] D.Hoornweg, Perinaz Bhada-Tata (2012) What a waste: A Global Review of Solid Waste Management, The World Bank March, No. 15 Washington, DC Urban development series knowledge papers.

IZVOD

\section{GRAD KAO URBANA KLASIFIKACIJA BIOSFERE I PROBLEM OTPADA}

U ovom radu su analizirane ekološke karakteristike grada kao posebno urbanizovane biosfere, uključujući važna pitanja u vezi sa reciklažom i razvojem zatvorenih tehnoloških sistema. Unapređenje upravljanja čvrstim otpadom jedan je od najefikasnijih načina za jačanje sveukupnog gradskog upravljanja $i$ ono predstavlja važan uslov za ostale komplikovanije gradske usluge. Čvrsti otpad je neminovno povezan sa urbanizacijom i sveukupnim ekonomskim razvojem. Danas više od 50\% ljudi živi u gradovima i nivo urabanizacije sve više raste. Do 2050. godine više ljudi će živeti u gradovima nego celokupno stanovništvo u svetu u 2000. godini. Ovo će svakako predstavljati dodatne izazove za odlaganje otpada. Stanovništvo, kompanije i gradovi će morati da preuzmu veću odgovornost za stvaranje i odlaganje otpada, posebno u oblasti dizajna proizvoda i odvajanja otpada.

Kjučne reči: grad, đubre, ekosistem, urbanizovana biosfera, zagađenje, otpad.

Pregledni rad

Rad primljen: 14. 03. 2015.

Rad prihvaćen: 05. 05. 2015.

Rad je dostupan na sajtu: www.idk.org.rs/casopis 